\title{
Disagreement and (im)politeness in a Spanish family members' WhatsApp group
}

\author{
Lucía Fernández-Amaya \\ Pablo de Olavide University \\ Carretera de Utrera, Km 1, 41013, Seville, Spain
}

\begin{abstract}
The present paper explores disagreement and impoliteness in a WhatsApp interaction within a Spanish family that took place during the 2018 International Women's Day. The conversation is linguistically examined using categories of disagreement strategies proposed by previous authors (Pomerantz 1984, Brown and Levinson 1987, Rees-Miller 2000, Locher 2004, Kreutel 2007, Malamed 2010, Shum and Lee 2013). Furthermore, multimodal analysis (Dresner and Herring 2010, 2013, Jewitt 2013, Bourlai and Herring 2014; Herring 2015) is used to consider not only participants' linguistic strategies for expressing disagreement, but also the function of multimedia elements and emojis (Dresner and Herring 2010, 2013, Yus 2014, 2017, Sampietro 2016a, 2016b, Aull 2019). The analysis is followed by an interview to better understand the participants' communicative intentions towards disagreements in relation to (im)politeness. A total of 427 instances of disagreement are identified, with the most common strategies being giving opposite opinions and emotional or personal reasons. This is to be expected since the group is divided from the very beginning into detractors and supporters of feminism, and they are also defending their opposite viewpoints by giving examples from their own life experience. Based on the participants' opinions, the most significant result is the fact that, although disagreement may lead to face-threat, and thus impoliteness in other contexts (Langlotz and Locher 2012, Sifianou 2012, Shum and Lee 2013), in this WhatsApp interaction, the Spanish family members did not consider it to be impolite, and it is even evaluated in positive terms by some of the participants (Angouri and Locher 2012).
\end{abstract}

Keywords: disagreement, (im)politeness, WhatsApp, digital communication, feminism, Spanish

\section{For citation:}

Fernández-Amaya, Lucía (2019). Disagreement and (im)politeness in a Spanish family members' WhatsApp group. Russian Journal of Linguistics, 23 (4), 1065-1087. doi: 10.22363/2312-9182-2019-234-1065-1087. 


\title{
Несогласие и (не)вежливость в общении членов испанской семьи в группе WhatsApp
}

Научная статья

\author{
Люсия Фернандес-Амайя \\ Университет имени Пабло де Олавиде, Севилья, Испания \\ Carretera de Utrera, Km 1, 41013, Seville, Spain
}

\begin{abstract}
Аннотация
В статье рассматривается выражение несогласия и (не)вежливость в общении членов испанской семьи по WhatsApp. Материал, ограниченный конкретным событием и датой - Международным женским днем 2018 г., анализируется с использованием стратегий выражения несогласия, предложенных ранее рядом авторов (Pomerantz 1984; Brown, Levinson 1987; Rees-Miller 2000; Locher 2004; Kreutel 2007; Malamed 2010; Shum, Lee 2013). Для рассмотрения не только языковых средств выражения несогласия, но и мультимедийных элементов и эмотиконок (Dresner, Herring 2010, 2013; Yus 2014, 2017; Sampietro 2016a, 2016b; Aull 2019) используется мультимодальный анализ (Bourlai, Herring 2014; Dresner, Herring 2010, 2013; Jewitt 2013; Herring 2015). Для лучшего понимания коммуникативных намерений участников общения при выражении несогласия и его восприятия с позиций (не)вежливости применялся метод интервью. Всего выявлено 422 случая выражения несогласия, при этом наиболее распространенными стратегиями являются высказывание противоположного мнения и объяснение эмоциональных или личных причин. Такой вывод представляется обоснованным, так как группа с самого начала делится на противников и сторонников феминизма, и они защищают свои противоположные точки зрения, приводя примеры из собственного жизненного опыта. Наиболее значимым результатом является тот факт, что, хотя несогласие может угрожать лицу собеседника и восприниматься как невежливость в других ситуациях (Langlotz, Locher 2012; Sifianou 2012; Shum, Lee 2013), в данном контексте, исходя из мнений участников, оно таковым не является, а, по мнению некоторых, даже оценивается положительно.
\end{abstract}

Ключевые слова: несогласие, (не)вежливость, WhatsApp, ичировая коммуникаиия, феминизм, испанский язык

\section{Для цитирования:}

Fernández-Amaya, Lucía (2019). Disagreement and (im)politeness in a Spanish family members' WhatsApp group. Russian Journal of Linguistics, 23 (4), 1065-1087. doi: 10.22363/2312-9182-2019-234-1065-1087.

\section{Introduction}

While it is true that the study of im/politeness and disagreement in digital communication is a growing field of research within pragmatics, most studies have focused on emails, social networking sites, discussion forums or blogs. Other digital means of communication, on the other hand, such as WhatsApp have received less attention. WhatsApp is the most popular mobile app for online dialogue among friends and family in Spain, with more than half a billion daily active Status users worldwide, up from 450 million global users in the second quarter of 2018, according to the website Statista ${ }^{1}$.

${ }^{1}$ https://www.statista.com/statistics/730306/whatsapp-status-dau/. 
Fundación Telefónica (2018) has reported that Instant Messaging (IM) tools such as WhatsApp, Facebook Messenger or Telegram are used twice as often as phone calls in Spain nowadays, with $95.1 \%$ of the Spanish population using them to communicate. $60 \%$ of the Spanish population send instant messages several times a day, while only $24 \%$ make mobile calls. In the Anglo-Saxon world, this is beginning to be known as 'Generation Mute', due to the preference for IM instead of traditional calls, a tendency that is even higher among Spain's young population: 96.8\% of Spanish citizens between 14 and 24 years old use WhatsApp as their preferred means of communication with family and friends.

Consequently, WhatsApp is increasingly gaining popularity among researchers as an object of study. This paper aims to contribute to the current academic research on this IM tool by exploring disagreement and impoliteness in a Spanish family members' WhatsApp group. More specifically, the analysis focuses on an interaction about feminism that took place on $8^{\text {th }}$ March 2018 (International Women's Day), beginning at 10.37 a.m., and ending on $9^{\text {th }}$ of March at 1.47 a.m. The reason for choosing this specific sample is that it is expected to be a locus of disagreement, since the participants are divided into supporters and detractors of feminism from the very beginning of the conversation.

Multimodal analysis (Dresner and Herring 2010, 2013, Jewitt 2013, Bourlai and Herring 2014, Herring 2015) was used to consider not only the linguistic strategies used by the participants to disagree with each other, but also the function of multimedia elements and emojis (Dresner and Herring 2010, 2013, Yus 2014, 2017, Sampietro 2016a, 2016b, Aull 2019). Furthermore, a follow-up interview was carried out to better understand the participants' communicative intentions and perceptions towards disagreements in relation to (im)politeness.

The paper is structured as follows: firstly, a literature review on digital discourse (with special reference to WhatsApp), disagreement and impoliteness is presented. This is followed by an explanation of the methodology applied to the analysis of the corpus in section 3. Then, the results are presented and analysed in section 4 and, finally, the paper closes with some conclusions.

\section{Literature review}

\subsection{Digital Discourse: WhatsApp}

WhatsApp, a mobile messaging service that began in 2009, accounts for a large proportion of typical daily smartphone usage in Spain. It is an IM application that, by means of an Internet connection, can be used to send messages, images, videos and audio files.

Researchers have focused on this application from different standpoints. Some have taken a sociological perspective (Church and Oliveira 2013, O'Hara et al. 2014, RubioRomero and Perlado Lamo de Espinosa 2015, Ándujar-Vaca and Cruz-Martínez 2017, Ersöz 2019), analysing the social effects of WhatsApp among its users, paying particular attention to its effects on students' learning and performance (Ahad et al. 2014, Bouhnik and Deshen 2014, Barhoumi 2015, among many others). In addition, WhatsApp use for 
healthcare communication has been analysed (Johnston et al. 2015, Kamel Boulos et al. 2016, Ganasegeran et al. 2017, among others).

From a linguistic perspective, researchers have centred on its multimodality (Calero Vaquera 2014, Sampietro 2016a, 2016b, Aull 2019), politeness (Flores-Salgado and Castineira-Benitez 2018), users' profile statuses (Sánchez-Moya and Cruz-Moya 2015b, Maíz-Arévalo 2018), the use of typographical variation (Sánchez-Moya and Cruz-Moya 2015a), the use of laughter as a resource to manage conversations (Petitjean and Morel 2017), its positive effects to increase phatic talk (Yus 2017) and the presence of conflict in WhatsApp interactions (García-Gómez 2018, Fernández-Amaya 2019). Like other kinds of mediated communication, WhatsApp digital interactions contain elements from both spoken and written varieties of the language (Crystal 2006, Baron 2008, Angouri and Tseliga 2010, Yus 2011, Jones and Hafner 2012, Pérez-Sabater 2012, 2015, Calero Vaquera 2014, Petitjean and Morel 2017). These characteristics include the use of emojis, words in other languages, lexicalization of vocal sounds and phonetic orthography, letter repetition, spelling and punctuation mistakes, abbreviations, acronyms, ellipsis, contractions, one-word transmissions, absence of openings and closings, short messages, and the possibility of having polylogal and convergent interactions, as well as asynchronous communication.

In spite of this increasing body of literature that has investigated the use of WhatsApp, there is no research on disagreement and impoliteness in this kind of mobile group interaction. The present study seeks to contribute to and increase the limited knowledge in this field.

\subsection{Disagreement and impoliteness}

Disagreement has been widely studied from many different perspectives such as Speech Act Theory (Sorning 1977, Mehregan et al. 2013, Netz 2014, Bardovi-Harlig et al. 2015), Politeness Theory (Rees-Miller 2000, Edstrom 2004, Sifianou 2012, Dynel 2015) or Preference Theory (Pomerantz 1984, Sacks 1987), among others.

It was initially seen as a face-threatening act (FTA), a "dispreferred" second, closely related to impoliteness (Brown and Levinson 1987, Sacks 1987, Pomerantz 1984, Culpeper 1996). In these studies, disagreement is considered something negative, a facethreatening act that may damage the social relationship between the interlocutors and, therefore, needs to be avoided or mitigated. With time, these views are reversed, as $\mathrm{Xu}$ (2017: 682) summarizes:

Fortunately, with the development of practical research, many scholars point out the non-inherent negativity of disagreement (e.g., Angouri \& Locher, 2012, p. 1549; Zhu, 2014, p. 87). Disagreement is an unmarked, preferred act and even the norm on some special occasions, like the activities of problem solving, decision making and commercial meeting, etc. (Tannen, 1981, 1998; Gray, 2001; Tjosvold, 2008; Angouri \& Locher, 2012), in which there needs to be thoughts in collision so as to improve scientificity or creativity of the solutions. Sometimes, disagreement can also be seen as a sign of intimate relationship or high social competence (Schiffrin, 1984, p. 311; Kakavá, 2002, p. 1562; Locher, 2004, pp. 280-281; Angouri \& Tseliga, 2010, p. 66; Sifianou, 2012, p. 1554). 
According to Locher (2004), there seem to be several factors that make disagreement preferred or not:

- culture: e.g., British indirectness contrasts with the predisposition to express opinions openly in Spanish (Hernández-López 2016);

- conversational style: e.g., high-involvement speakers versus high-considerateness speakers (Tannen 1984);

- the speech situation: this is directly related to the concept of genre, defined by Swales (1990: 58) as "a class of communicative events, the members of which share some set of communicative purposes". Recent studies, following Garcés-Conejos Blitvich (2010), have emphasized this genre approach to account for specific linguistic choices (Fernández-Amaya et al. 2014, Hernández-López 2016; Hernández-López and Fernández-Amaya 2019). In this vein, whether the behaviour of speakers when expressing disagreement is perceived as impolite or not by the interactants may depend on the frames and norms relevant for the specific situation;

- participants' age, status or gender: e.g., men appreciating disagreement more than women (Tannen 1990);

- topic: the more controversial a topic is, the riskier it is to express a different opinion (Kakavá 1993);

- a participant's topic engagement and familiarity: even interlocutors in the same speech situation and from the same background may have different expectations and a different tolerance level for disagreement (Kakavá 1993).

Disagreement can be a preferred response when a frame of argumentation is established and opponents are expected to defend their point of view, as is the case of the interaction in this paper. However, it is important to point out that, as Langlotz and Locher (2012: 1591) indicate, "conflictual disagreements are closely linked to negative emotional reactions, especially when one feels offended or treated rudely". Therefore, knowing interlocutors' opinions becomes crucial when interpreting a disagreement episode as impolite or not.

As a linguist, I am not only interested in the presence or absence of disagreement but in observing how it is enacted and achieved and what the effects of the different renditions may be. For this reason, it is against the theoretical background presented that this study of disagreement and impoliteness in WhatsApp interaction seeks to answer these two research questions:

1) What are the linguistic realizations used by participants to express disagreement?

2) How do participants judge impoliteness in disagreement?

\section{Methodology}

\subsection{Data}

The corpus for this study is made up of a real WhatsApp interaction that began at 10:37 a.m. on the $8^{\text {th }}$ March and ended at 1:47 a.m. on the $9^{\text {th }}$ March (so slightly during more than 14 hours). The general topic of this conversation of circa 9,900 words in Spanish was feminism all the time. As was stated in the introduction, the reason for choosing this specific sample as an object of analysis is that it is expected to be a locus 
of disagreement, since the participants are divided into supporters and detractors of feminism from the very beginning of the conversation.

The contributors are 11 family members from a middle-class family in the South of Spain. One of the participants is the researcher but, since the interaction substantially predated any analytical intention, there was no observational pressure on any side. Although the WhatsApp group is made up of 13 members, 2 of them decided not to participate in this conversation.

Table 1

Participants' information

\begin{tabular}{|l|l|l|}
\hline \multicolumn{1}{|c|}{ PARTICIPANT } & \multicolumn{1}{c|}{ AGE } & \multicolumn{1}{c|}{ GENDER } \\
\hline Julio* & 32 & Male \\
\hline Natalia & 26 & Female \\
\hline Linda & 32 & Female \\
\hline Berta & 34 & Female \\
\hline Lola & 43 & Female \\
\hline Ramón & 34 & Male \\
\hline Dora & 56 & Female \\
\hline Ana & 35 & Female \\
\hline Isabel & 42 & Female \\
\hline Félix & 27 & Male \\
\hline Marina & 60 & Female \\
\hline
\end{tabular}

*All participants' names are pseudonyms.

6 months after the interaction took place, all the participants were very briefly informed about my research aims and the fact that the data were going to be treated anonymously, giving their consent to the use of their interaction in the study. The relationships between the participants can be seen in Figure 1 below:

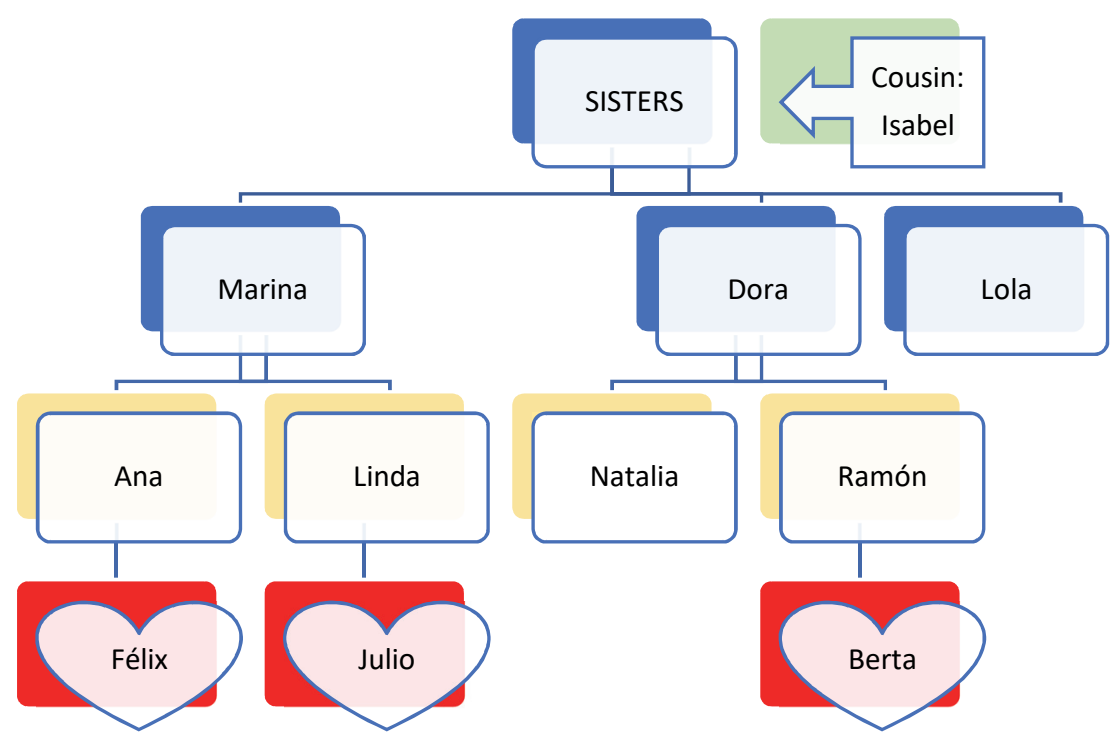

Figure 1. Participants' relationship 
Apart from the two participants who decided not to contribute to the conversation, in this WhatsApp group there are 3 sisters (Marina, Dora and Lola) and their cousin Isabel. Marina has two daughters, Ana and Linda, who are married to Félix and Julio, respectively. Dora has a daughter (Natalia) and a son, Ramón, who is married to Berta. The relationship between all the participants is very close since they see each other frequently and they get along very well.

The interaction analysed here begins with the following two interventions made by Lola:

1) $8 / 3 / 18$ 10:37: Lola:

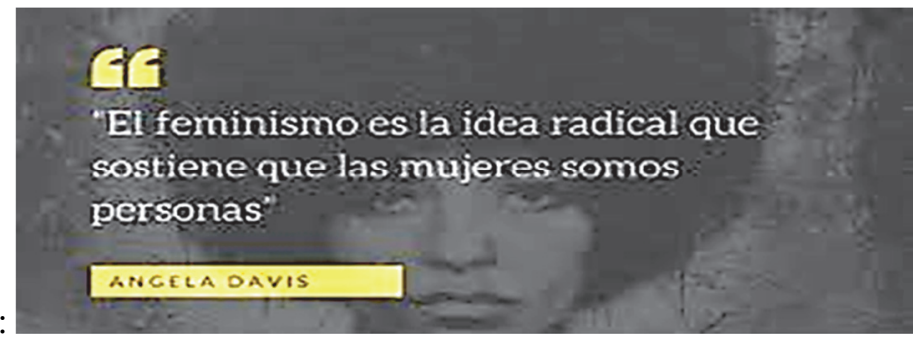

2) 8/3/18 10:37 — Lola: Buenos días!! 鸟鸟 (Good morning!! 阽鸟)

Lola posts a meme with a famous definition, wrongly attributed to Angela Davis: "Feminism is the radical notion that women are people". After that, she greets the whole group and uses two emojis of arms showing strength. By means of the double exclamation marks and the emojis, she is adding emotion towards the propositional content of this utterance, showing support to this idea of feminism and the need to fight for it on a day like the 8 th of March.

Immediately, these 2 contributions divide the members of this WhatsApp group into two main opposing streams, related to the ideological positioning of participants: those who are in favour of feminism and consider it is important to participate in the demonstrations scheduled for International Women's Day in order to fight for women's rights (Lola and Linda), and those who are against it because they feel there is no need to demonstrate at all (Julio, Ramón, Berta). There is also a third group of participants that do not position themselves clearly at either of these two extremes because they change their viewpoint depending on the specific issue regarding feminism under discussion (Natalia, Ana, Dora) or because they do not express their opinion in an open way (Félix, Isabel).

Due to these antagonistic views, the interaction analysed here is characterised by a strong presence of disagreements used by participants in order to defend their position as supporters or detractors of feminism.

\subsection{Analytical framework}

Following the discursive approach to (im)politeness, the identification of disagreement strategies in the corpus was based on a series of WhatsApp turns (at least two) while participants were interacting with one another. It is important to point out here that, in this analysis of a polylogue with 11 participants, comments may be misplaced (i.e. a participant's response may not appear just after the comment it targets) and agreeing with one person can imply disagreeing with another family member. For this reason, 
it was really important to pay attention to the content and addressivity to understand how messages were connected to each other (Bolander 2012, Bou-Franch, Lorenzo-Dus and Garcés-Conejos Blitvich 2012, Sifianou 2012).

It goes without saying that participants may opt for more than one strategy in a single WhatsApp message, as will be seen in the examples shown in the next section. In other cases, a single disagreement strategy was developed through several WhatsApp messages, sometimes even with other participants commenting at the same time. This is due to the possibility of having convergent interactions, as well as asynchronous communication that, as we saw in the previous section, are characteristic of this type of polylogal digital interactions.

Interlocutors' assessments of each other's interventions were crucial in this identification that was carried out using the following list of 16 disagreement strategies, taken and adapted from previous works (Pomerantz 1984, Brown and Levinson 1987, Rees-Miller 2000, Locher 2004, Kreutel 2007, Malamed 2010 and Shum and Lee 2013). The reason for choosing these strategies is that all of them relate, in some way or another, disagreement with considerations of politeness and/or relational work, as in the present study. All the examples from this list except for "Expressing regret" have been taken from the corpus and translated into English:

1. [UD] Using unmitigated disagreement: by means of bare negative forms (e.g. "no", "no way") or the performative (e.g. "I disagree", "I don't/can't agree").

2. [HED] Using mitigating expressions (hedges) (e.g. "I guess", "it seems").

3. [TA] Token agreement (e.g. "yes ... but").

4. [NC] Giving negative comments: the participant expresses what s/he thinks to be the right thing to do and compares with what $\mathrm{s} /$ he thinks is the wrongdoing of the interlocutor in a personalised way (e.g. "There are schedules that directly do not allow you to become a mother").

5. [VP] Using short vulgar phrases: the participant uses taboo words (insults, swear words, etc.) when disagreeing with the interlocutor (e.g. "today, instead of demonstrating, I went to the hospital to see my neighbour who is really fucked up").

6. [OAQ] Expressing objection as a question: the participant questions the interlocutor's previous claim (e.g. "do you really think so?”).

7. [RC] Requesting clarification (e.g. "you are saying I am right, aren't you?").

8. [IS] Making an ironic statement: the participant says something insincerely (e.g. "Come on, now Diana Quer was killed for being a man").

9. [JOKE] Joking: avoiding a clear statement of disagreement but it may be understood as such (e.g. "have you been possessed by a spirit from the middle ages?").

10. [OO] Giving opposite opinions: the participant disagrees by giving an opinion that is contrary to what was said before. There is no intention of giving negative comments (e.g. “A: children are an obstacle to a woman's career. B: If a man has custody of his children, I doubt he can be promoted a lot"). 
11. [REW] Rewording: the participant shows disagreement by making minor changes to the interlocutor's original comments instead of repeating the utterance (e.g. "A: And you're still wondering why we are demonstrating?? B: I don't wonder why you're demonstrating.).

12. [EPR] Giving emotional or personal reasons: referring to personal experience to substantiate disagreement (e.g. "I am demonstrating for those who fought before and could not complete their work.")

13. [FAC] Giving facts: disagreeing using quotations, statistical information, pictures, videos, etc. to show a completely opposite view (e.g. "I know many women who, knowing they are protected by law, have reduced their work performance by $50 \%$ after giving birth").

14. [ER] Expressing regret (e.g. "I'm sorry but I don't agree").

15. [SUG] Making suggestions (e.g. "I would like you to demonstrate for all those women who fought, were forced to submit or died").

16. [REP] Reprimanding: the participant tells the interlocutor that his/her action/ behaviour/attitude is not approved (e.g. "if we all stay at home, we don't increase the problem's visibility").

\subsection{Procedure}

The data analysis involved several steps. First, the interaction was forwarded from the mobile phone to an email account as an attachment, thus preventing transcription errors. After copying the text into a Microsoft Word document, all interventions were subjected to an anonymization process in which participants' names and other personal references were veiled.

Then, the interaction was analysed in search of the 16 disagreement strategies mentioned before. In order to establish coder reliability, the corpus was coded separately by the author and a research assistant and any discrepancies (less than 15\% for each code) were resolved through discussion. Finally, since, as an analyst, I can only interpret what participants convey on the basis of their utterances, they were asked the following questions to ascertain their opinion towards disagreement and impoliteness:

1. Were you offended/upset by any of your interlocutors' comments? If so, can you indicate when and why? If not, why not?

2. Do you consider any of the comments to be impolite? If so, can you indicate which one(s) and why? If not, why not?

3. Have these comments had any consequences in your relationship with this person after this WhatsApp interaction?

\section{Results and discussion}

In the following sub-sections, the variety of disagreement strategies found is presented, juxtaposed with examples. Then, the participants' judgement of impoliteness is summarised.

\subsection{Disagreement strategies}

A total of 427 disagreement instances were identified, with the strategy distribution presented in Figure 2. 


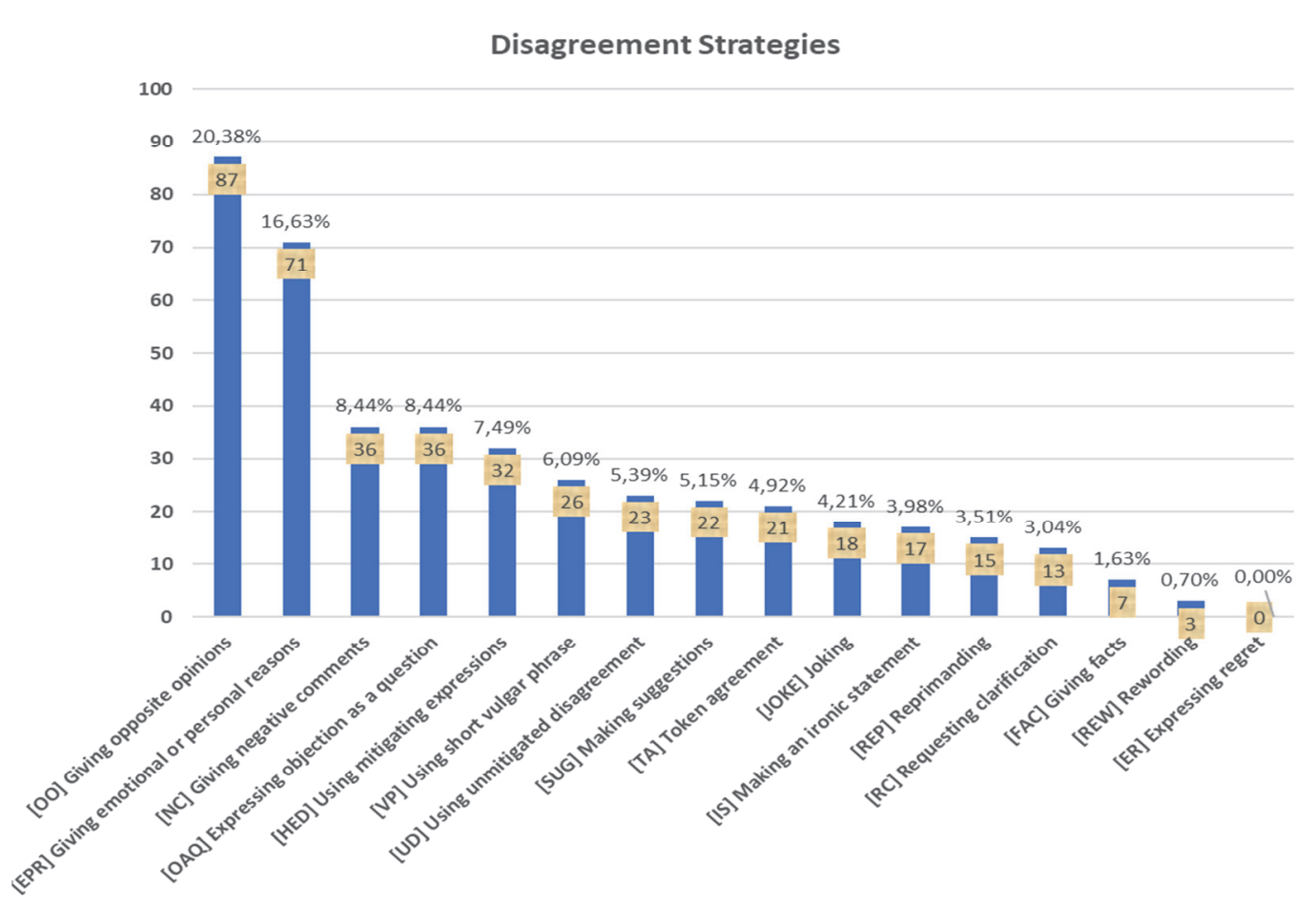

Figure 2. Disagreement instances $(\mathrm{N}=427)$

"Giving opposite opinions" and "Giving emotional or personal reasons" were the two most widely used strategies, employed on more than $37 \%$ of occasions. This is to be expected, bearing in mind that the group is divided from the very beginning into detractors and supporters of feminism, and they are defending their opposite viewpoints by also giving examples from their own experience.

The rest of the disagreement strategies were present with lesser frequency, although there was no instance of "Expressing regret" (e.g. 'I'm sorry but I don't agree'). One possible explanation could be that these kinds of expressions are typical of specific cultures such as British English, more oriented towards deference and negative politeness. However, this is not the case in peninsular Spanish, more oriented towards solidarity and positive politeness when it comes to family and friends' interactions.

Furthermore, the insignificant presence of the "Rewording" strategy, with only 3 instances, could be explained by the fact that participants are often so eager to express their opinion that they write at the same time and do not read each other's messages. Consequently, rewording is less likely to happen. These overlaps contribute to a more conversational and heated debate, as in an oral exchange.

Surprisingly, there was a low occurrence of the "Unmitigated disagreement" strategy, only used in $5.39 \%$ of the total amount. This contradicts previous findings that suggest "unmitigated disagreement can occur in contexts where it is more important to defend one's point of view than to pay face consideration to the addressee" (Locher 2004: 143). I expected a higher occurrence of this strategy, since the main purpose of this interaction was precisely that, and the familiar relationship between the participants also permitted the use of this strategy. 
As we can observe in Table 2, almost $73.31 \%$ of the disagreement strategies are used by four participants, who are core members in the conversation: Julio and Linda, who form a couple, as well as Berta and Natalia. Thus, the participants, despite being in the same speech situation and having the same background, employ disagreement strategies in different frequencies. This might point to a difference in tolerance of disagreement (Kakavá 1993), as was stated in the literature review.

Table 2

Disagreement strategies per participant*

\begin{tabular}{|c|c|c|c|c|c|c|c|c|c|c|c|c|}
\hline Disagreement strategy & $\begin{array}{l}\frac{\pi}{c} \\
\stackrel{5}{=}\end{array}$ & 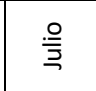 & $\begin{array}{l}\frac{\frac{\pi}{1}}{\pi} \\
\frac{\pi}{2}\end{array}$ & 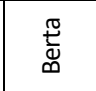 & 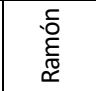 & $\frac{\pi}{0}$ & $\frac{\pi}{\circ}$ & $\stackrel{\frac{\pi}{2}}{\frac{\pi}{4}}$ & $\begin{array}{l}\overline{\mathbb{d}} \\
\stackrel{\mathbb{\mathbb { D }}}{\underline{M}}\end{array}$ & $\frac{\sqrt[x]{\bar{U}}}{4}$ & $n=$ & $\begin{array}{c}\% \text { of } \\
\text { strategy }\end{array}$ \\
\hline $\begin{array}{l}\text { [OO] Giving opposite } \\
\text { opinions }\end{array}$ & 20 & 26 & 13 & 9 & 7 & 4 & 4 & 3 & & 1 & 87 & $20.38 \%$ \\
\hline $\begin{array}{l}\text { [EPR] Giving emotional } \\
\text { or personal reasons }\end{array}$ & 15 & 7 & 10 & 21 & 4 & 5 & 3 & 4 & 2 & & 71 & $16.63 \%$ \\
\hline $\begin{array}{l}\text { [OAQ] Expressing } \\
\text { objection as a question }\end{array}$ & 12 & 5 & 10 & 4 & 2 & 2 & 1 & & & & 36 & $8.44 \%$ \\
\hline $\begin{array}{l}\text { [NC] Giving negative } \\
\text { comments }\end{array}$ & 7 & 7 & 4 & 7 & 5 & 4 & & 1 & & 1 & 36 & $8.44 \%$ \\
\hline $\begin{array}{l}\text { [HED] Using mitigating } \\
\text { expressions }\end{array}$ & & 8 & 11 & 5 & 5 & & 1 & 2 & & & 32 & $7.49 \%$ \\
\hline $\begin{array}{l}\text { [VP] Using short vulgar } \\
\text { phrases }\end{array}$ & 5 & 5 & 4 & 2 & 4 & & 6 & & & & 26 & $6.09 \%$ \\
\hline $\begin{array}{l}\text { [UD] Using unmitigated } \\
\text { disagreement }\end{array}$ & 8 & 5 & 3 & 4 & & 1 & & 2 & & & 23 & $5.39 \%$ \\
\hline $\begin{array}{l}\text { [SUG] Making } \\
\text { suggestions }\end{array}$ & 3 & 4 & 8 & 2 & & 1 & 2 & 1 & 1 & & 22 & $5.15 \%$ \\
\hline [TA] Token agreement & 6 & 2 & 2 & 5 & 4 & 1 & & 1 & & & 21 & $4.92 \%$ \\
\hline [JOKE] Joking & 3 & 9 & & 2 & 1 & 3 & & & & & 18 & $4.21 \%$ \\
\hline $\begin{array}{l}\text { [IS] Making an ironic } \\
\text { statement }\end{array}$ & 4 & 1 & 3 & & 7 & 2 & & & & & 17 & $3.98 \%$ \\
\hline [REP] Reprimanding & 8 & & & & 1 & 3 & 3 & & & & 15 & $3.51 \%$ \\
\hline $\begin{array}{l}\text { [RC] Requesting } \\
\text { clarification }\end{array}$ & & & 8 & & 3 & 2 & & & & & 13 & $3.04 \%$ \\
\hline [FAC] Giving facts & 1 & 3 & & & & 3 & & & & & 7 & $1.63 \%$ \\
\hline [REW] Rewording & 1 & 1 & & & & & & 1 & & & 3 & $0.70 \%$ \\
\hline [ER] Expressing regret & & & & & & & & & & & 0 & $0.00 \%$ \\
\hline$n=$ & 93 & 83 & 76 & 61 & 43 & 31 & 20 & 15 & 3 & 2 & 427 & \\
\hline $\begin{array}{l}\text { \% of contribution } \\
\text { per person }\end{array}$ & $21.77 \%$ & $19.47 \%$ & $17.79 \%$ & $14.28 \%$ & $10.07 \%$ & $7.25 \%$ & $4.68 \%$ & $3.51 \%$ & $0.70 \%$ & $0.46 \%$ & $100 \%$ & \\
\hline
\end{tabular}

*Marina has not been included in this chart because none of her five contributions to the conversation is a disagreement.

Both Julio and Linda are very active participants in the chat from the very beginning and they keep on contributing with different interventions non-stop during the 14-hour conversation. However, although Berta and Natalia also participate in the morning, their involvement in the conversation increases when the demonstration has already taken place. This evening part of the interaction seems to be the moment in which the conflict is more heated. Lola and Linda have been posting photos, videos and comments showing what an awesome experience it has been for them participating in the demonstration. Although they are not specifically addressing anybody in the group, these comments seem to have threatened other participants' face, who deem it necessary to justify why they have not demonstrated. Thus, the participants make use of disagreement strategies 
in order to (dis)affiliate themselves from/with one of two social identities: supporters and detractors of feminism.

Regarding the kind of strategies used by each participant, we can see that the most frequent strategies used coincide with the general results: "giving opposite opinions" and "giving emotional or personal reasons". However, there are specific results that are worth commenting on. For example, Linda does not make use of any hedge at all, disagreeing bluntly with all participants. Furthermore, she is the participant who employs most often the strategy "reprimanding". This contrasts with Natalia's conversational style, for instance, who is the participant who uses the most mitigation and no reprimand. From the general content of the conversation, we can deduce that Linda is a strong defender of feminism and does not understand how other members of her family can be against it, even worse, female participants. However, Natalia's opinion towards feminism changes depending on the issue being dealt with, which may explain her use of hedges. Thus, as seen in the literature review, conversational style also influences the way in which disagreement is presented (Tannen 1984, Locher 2004).

Another result which is worth highlighting is Berta's use of "giving emotional or personal reasons". As can be observed in Table 2, she is the participant who uses this strategy the most. Berta seems to be threatened by other participants' willingness to participate actively in the defence of women's rights for equality. So, the high use of this strategy could be related to the fact that she feels the need of justifying herself for being against feminism, giving personal reasons for her decision.

Below are some examples taken from the analysis to contextualise how participants used these strategies. They are in time sequence and have been chosen because they illustrate different strategies very clearly in a single extract. All the examples have been copied verbatim without any corrections.

\section{Example 1}

1) $8 / 3 / 18$ 12:55 — Lola: https://elpais.com/elpais/2018/03/07/icon/1520426823_220468.html ("Hoy te han dejado de niñera". 43 micromachismos que cometemos a diario) ("Today you are babysitting": 43 sexist comments we make everyday)

2) 8/3/18 12:56 - Lola: Me temo que en este grupo hay personas que hacen algunos de la lista y no quiero señalar pero empiezo por mi casa.... (2) (I'm afraid there are people in this group who make some of those mentioned on the list and I don't want to point my finger at anybody but I am starting in my own home...:)

3) 8/3/18 14:12 - Berta: En mi casa no pasa na de ezo (None of that happens at my home) [Emotional or Personal Reasons] $[\ldots]$

4) 8/3/18 14:17 — Linda: Que suerte miarma! Te has llevado una joya!! (You lucky girl! You married a treasure!!) [Ironic Statement]

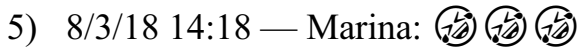

2 Although in English this expression is not gender marked, in Spanish "dejar de niñera" refers to a female. Thus, when applied to a man, it may have negative connotations implying that he is carrying out an action that is supposed to be done by a woman. That is why in the newspaper article this expression is considered sexist, since taking care of kids is no longer solely part of a woman's responsibilities. 
6) 8/3/18 14:24 - Ramón: Hay cosas extendidas en la lista pero habrá q hacer otra lista al revés. (There are some things on the list that are widespread but there needs to be another list for things the other way around.) [Token Agreement]

7) $8 / 3 / 18$ 14:33 - Julio: El 95\% de los fallecidos fueron hombres (95\% of the deceased were men)

8) 8/3/18 14:33 - Julio: https://m.eldiario.es/economia/accidentes-laborales-sumaronmuertes-noviembre_0_729677194.html

9) 8/3/18 14:33 - Julio: Tenemos los trabajos más precarios y peligrosos (We have the most precarious and dangerous jobs) [Negative Comments + Facts]

10) 8/3/18 14:33 - Julio: De esto no se habla (This is not mentioned) [Opposite Opinion]

$[\ldots]$

11) 8/3/18 14:37 - Julio: En 1912 es verdad que no podian votar, pero si se hundía un barco, tenían preferencia 2 Yo prefiero no votar y meterme en un bote salvavidas 3

(It's true they couldn't vote in 1912 but, if a ship was sinking, they were given priority (3) I prefer not to vote and get into a lifeboat (Joke + Emotional or Personal Reasons]

12) 8/3/18 14:38 - Julio: Fite el Leonardo di caprio, con el espacio que tenía en el trozo tabla la muchacha, yto pa ella [Just look at Leonardo di caprio, with all the space the girl had on that board, and all to herself] [Joke]

In this first example, Lola posts a link to a newspaper article that contains a list of sexist comments people make every day. Then, she accuses, in general terms, the members from the chat of exhibiting this kind of sexist behaviour. This contribution immediately obtains a number of responses that disagree with this idea. The first one is by Berta (Line 3) who provides a simple denial of the propositional content of the FTA made by Lola, giving personal reasons to support her disagreement. Berta mitigates this potential FTA by means of positive politeness strategies, changing the spelling of "none" ( $n a$ instead of nada) and "that" (ezo instead of eso), trying to give an informal tone to her message, making it more oral. This kind of unconventional spelling is also used by Ramón in line 6 ( $q$ instead of que) and Julio in line 12 (fite instead of fijate, to instead of todo and pa instead of para). This is one of the characteristics of, not only WhatsApp interactions, but digital discourse in general:

As shown by other work in the field (Crystal 2006), the use of repeated keystrokes and unconventional orthography has often been documented as an effort on the part of the interactants to compensate creatively for the effects of gesture and tone in the CMC context. (Angouri \& Tseliga 2010, 70).

In line 4, Linda does not believe what Berta is saying and she disagrees using an ironic statement by means of which she says something insincerely, using double exclamation marks to strengthen her emotions. Ramón responds using a token agreement admitting there may be some logic to making the list but then offers an explanation that shows that he does not agree fully to it, since he links the need for such a list to a similar need for another list "the other way around" (line 6). 
Julio expresses his disagreement with the feminist movement by posting a newspaper article in order to give facts related to his idea that it is men, not women, who are in a disadvantaged position. In an effort to support his argument, he moves from a personal identity to a group identity ("we have") and uses negative comments to describe men's jobs.

In line 10, he also gives an opposite opinion, i.e. an opinion that is contrary to what is said but without any intention of making negative comments. Then, he jokes in lines 11 and 12, a strategy by means of which he avoids a clear statement of disagreement, but may be understood as such.

The presence of the emojis is also worth pointing out, since in this case they help to add a friendly tone to the debate, trying to reduce face-threat (Maíz-Arévalo 2014). Julio uses them to signal he is joking, being one of the instances of bonding humour (Hay 2000, Schnurr 2010) present in the analysis, which creates and reinforces solidarity and common ground.

In the next two hours between when examples 1 and 2 took place, the discussion on feminism continues with some of the participants providing different arguments for (Lola, Linda) or against (Julio, Ana, Dora, Berta) it.

\section{Example 2}

1) 8/3/18 16:23 - Berta: Yo los extremos no los q veo en ningun caso buenos (I do not consider extremes to be good in any case) [Hedge + Negative Comment]

2) 8/3/18 16:24 - Dora: Además de verdad (You're so right $[\ldots]$

3) 8/3/18 16:25 - Berta: En mi casa ni en ninguna parte habra ni machismo ni feminismo, pq yo me encargare de educar a mis hijos asi, como me educaron a mi (There will be no machismo nor feminism anywhere in my home, cos I'll take care of raising my children that way, as I was raised) [Emotional or Personal Reasons] $[\ldots]$

4) 8/3/18 16:32 - Berta: Pero a mi q no me.digan heteropatriarcado capitalista (But don't talk to me about capitalist heteropatriarchy) [Opposite Opinion]

5) 8/3/18 16:32 — Berta: Que no (No way) [Unmitigated Disagreement]

In example 2 we see that Berta, who is against feminism, uses hedges and negative comments to show her disagreement with the members of the group who are in favour of it. This receives a positive response from Dora, who emphasizes her agreement with Berta's statement with 3 clapping hands emojis (line 2). Then, in line 3, Berta refers to emotional or personal reasons to support her disagreement.

Finally, in line 4, she disagrees by giving an opinion that is contrary to what is said and she ends using unmitigated disagreement by means of the bare negative form "no way". This way Berta is dissociating herself from those who are in favour of feminism, implicitly associating something negative with them.

After this extract, the discussion on feminism continues mainly between Lola and Linda, who are getting ready for going to the demonstrations, and Julio, who is all the time disagreeing with them by giving reasons against the need to fight for women's rights. Example 3 takes place after Lola has told how a friend of her has just received a sexist comment from the taxi driver who was taking her to the demonstrations. 


\section{Example 3}

1) 8/3/18 18:44 — Lola: Y aún os preguntáis por que nos manifestamos?? (And you still wondering why we are demonstrating??) [Objection as question]

2) 8/3/18 19:14 - Julio: Yo no me pregunto porque os manifestais. (I don't wonder why you're demonstrating.) [Rewording]

$[\ldots]$

3) 8/3/18 23:09 - Ramón: Q leyes tienen q cambiar? (What laws need to change?) [Requesting clarification]

$[\ldots]$

4) 8/3/18 23:10 - Dora: Joder esto no se acaba, hacer cada uno lo q os salga del perrete (-1) (Bloody hell, this is never ending, just do whatever the hell you feel like (-) -9) [Vulgar phrase + Reprimanding + Suggestion]

The rest of the strategies found in the corpus are seen in example 3 above:

- "Expressing objection as a question" (line 1). By means of this question, Lola is showing her disagreement with the members of the group who have stated that it is not necessary to demonstrate on the $8^{\text {th }}$ of March to fight for women's rights.

- "Rewording" (line 2). In this case, the participant shows disagreement by making minor changes to the interlocutor's original comments. This strategy is used by Julio to disagree with Lola's previous statement.

— "Requesting clarification" (line 3). This question gives the interlocutor the possibility of explaining and clarifying their point to avoid possible disagreement. This is a common strategy used by Ramón, who is one of the members of the group against feminism.

— "The use of short vulgar phrases such as insults or swear words" and "Reprimanding", through which the participant tells the interlocutor that their action, behaviour or attitude is not approved, as seen in line 4. As stated previously, Dora is one of the members of the group without a clear-cut opinion for or against feminism. In this case, she disagrees with the general attitude of the conflictive interaction and tells the rest off for arguing for so long. Once again, here emojis help to reduce face-threat and add a friendly tone.

\subsection{Participants' opinions}

In order to ascertain their opinion towards disagreement and impoliteness, participants were asked the following questions:

1. Were you offended/upset by any of your interlocutors' comments? If so, can you indicate when and why? If not, why not?

2. Do you consider any of the comments to be impolite? If so, can you indicate which one(s) and why? If not, why not?

3. Have these comments had any consequences in your relationship with this person after this WhatsApp interaction?

The questions were sent by email to the different participants together with the transcription of the interaction. At this stage it is important to address whether responses can be expected to reflect the feelings and reactions of the participants at the time, or whether there might be a positivity bias that would lead the answers to lean towards 
claiming that no face-threats occurred in order to maintain a positive image/face of the family as a whole. Given the fact that the author is a member of this community of practice, the participants were assured that their feedback was not going to be revealed to the rest of the members in the group (hence no names are given below), so that they could express freely what they thought and their responses could be helpful for my research goals. In fact, since they do not speak English and they are not scholars, they have shown no interest in knowing the results of the research carried out.

Regarding the first question, 10 out of 11 participants answered that they were not offended or upset by their interlocutors' comments. The explanations given justifying their answers include the following:

P1: "Conozco a los integrantes del grupo y no lo hacen para ofender. Están expresando sus ideas y las respeto." (I know the members of the group and they don't do it to offend anybody. They are expressing their ideas and I respect them.)

P2: "No me ha molestado nada, cada uno puede pensar como quiera. Sí me ha sorprendido la reacción de algunas personas. " (Nothing bothered me, people can think what they want. But I was surprised by some people's reaction.)

P3: "Sinceramente no me molestaron ninguno de los comentarios. Aunque no estaba de acuerdo con muchas de las cosas que se decían entiendo que no todo el mundo tiene un mismo pensamiento." (Honestly, none of the comments bothered me. Although I didn't agree with many of the things that were said, I understand that not everyone has the same thought.)

Disagreement for these participants has no face-aggravating effects (Goodwin 1983, Schiffrin 1984, Georgakopoulou 2001). Despite dealing with a controversial topic (feminism), since they are in a relationship of solidarity and share interactional norms delimited by the specific genre, disagreement seems to be appropriate and does not violate relational boundaries.

In relation to the second question, none of the participants considered any of the comments to be impolite. Some of their explanations were:

P3: "No creo que haya comentarios maleducados. Entiendo que se enmarcan dentro de la confianza que existe en un grupo de wasap familiar." (I don't think there are impolite comments. I believe they are part of the mutual trust that exists in a family wasap group.)

P4: "Para nada, creo que ha sido una conversación muy interesante y educadora." (Not at all, I think it was a very interesting and educational conversation.)

In order to decide what is and is not polite, P3 refers to the set of community norms defined by the group of which he is a part. He explains that he does not consider the comments to be impolite because there is "confianza" (trust) among participants. This term has been used by different pragmaticians to account for the fact that, in interactions among friends and family in Spain, having this mutual trust allows participants to speak their minds. Thus, they can disagree with each other without any fear of offending their interlocutors (see, among others, Hernández-Flores 2003, Bernal 2007 , Bravo 2008). 
In the same vein, not only does P4 not consider the conversation to be impolite at any time, but she also sees disagreeing as an entertaining activity that may foster sociability (Georgakopoulou 2001, Sifianou 2012).

All the participants also answered the third and final question in a negative way. Among the explanations given were:

P4: "Para nada!! Sigo exactamente igual con todos. De hecho deberiamos tener más discusiones en el grupo!" (No way!! I am still on exactly the same terms with everyone. In fact we should have more discussions in the group!")

P2: "No, pero opino que el WhatsApp puede dar problemas. No es lo mismo una conversación donde estás viendo a la persona y ves su reacción (gestos, miradas, ...) que imaginártelo." (No, but I think WhatsApp can pose problems. It's not the same as having a conversation in which you see the other person and their reaction (gestures, expressions...) as imagining it.)

P1: "Por supuesto que no. Respeto las ideas que cada uno tenga aunque no las comparta." (Of course not. I respect their ideas even if I may not agree with them.)

From these answers, we can deduce that the occurrence of disagreement does not seem to threaten participants' relationships in this group. In fact, P4 sees it once again as an entertaining activity. P2 makes reference to the fact that the lack of non-verbal cues may make it more difficult to interpret the interlocutors' intention, as other researchers analysing (im)politeness in CMC have already stated (Graham 2007).

\section{Conclusions}

The present paper has contributed to the existing, limited research on WhatsApp interaction in languages other than English by analysing disagreement and impoliteness in an interaction within a Spanish family on the 8th March 2018. The main purpose of the analysis was to answer the two guiding research questions:

1) What are the linguistic realizations used by participants to express disagreement?

2) How do participants judge impoliteness in disagreement?

In relation to the first research question, the linguistic strategies proposed by different authors were present in the corpus with more or less frequency, with the most common strategies being "giving opposite opinions" and "giving emotional or personal reasons". This is reasonable since the group is divided from the very beginning, and the fact that participants (dis)affiliated themselves from/with one of two social identities (supporters and detractors of feminism) made disagreement the norm in this interaction.

It is worth noting there was no instance of the strategy "Expressing regret". As stated previously, this could be explained by the differences in politeness orientation between English and peninsular Spanish. This finding supports the need to analyse disagreement in languages other than English. Another remarkable result was the low occurrence of the strategy "Unmitigated disagreement", since the familiar relationship between the participants permitted the use of this strategy, as it is derived from the answers the participants gave after the interview. In my opinion, this may be related to the fact that the participants want to make it very clear which side of the conflict they are taking, developing their explanations and providing reasons for their disagreement. 
The analysis has also revealed that it is important to examine how disagreement evolves across multiple turns, since it has not developed in a linear way, with different answers from various members, sometimes even writing at the same time, and with side sequences. Thus, it is necessary to approach the analysis of disagreement not only from a synchronic but also from a diachronic perspective.

Another issue that it is worth highlighting is the role played by multimodal elements and emojis with different functions related to disagreement, such as being the origin of disagreement itself (i.e. the first meme and the links to the news story in example 1), showing disapproval with others' opinions, intensifying disagreements to show emotion or trying to reduce face-threat and boosting group solidarity (as in example 3).

In relation to the second research question, as shown by the participants' opinions, the fact that they are family members and have known each other for a long time makes the impact of their disagreement different from that of speakers in antagonistic relationships. Therefore, in this case, although the topic is controversial it does not seem to be risky for the participants to express a different opinion, contradicting what previous authors have stated (Kakavá 1993, Locher 2004). In this context, disagreement is not considered to be impolite and is even evaluated in positive terms by some of the participants. Hence, the findings of this study are in line with the contemporary consensus that disagreement is not a priori a negative speech act (Angouri and Locher 2012). Thus, disagreement is not an inherently impolite act that should always be avoided or mitigated.

(C) Lucía Fernández-Amaya, 2019

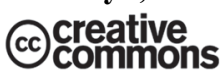

https://creativecommons.org/licenses/by/4.0/

\section{ACKNOWLEDGMENTS}

I would like to thank the participants in the study since this research would not have been possible without their consent. I am also indebted to the editors of this special issue and the anonymous reviewers for their helpful comments.

\section{REFERENCES}

Ahad, Annie Dayani \& Ariff Lim, Syamimi Md (2014). Convenience or nuisance?: The 'WhatsApp' dilemma. Procedia-Social and Behavioral Sciences, 155, 189-196. doi: 10.1016/j.sbspro.2014.10.278.

Andújar-Vaca, Alberto \& Cruz-Martínez, María Soledad (2017). Mobile instant messaging: Whatsapp and its potential to develop oral skills. Comunicar, 25 (50), 43-52. doi: 10.3916/C50-2017-04.

Angouri, Jo \& Locher, Miriam A. (2012). Theorising disagreement. Journal of Pragmatics, 44 (12), 1549—1553. doi: 10.1016/j.pragma.2012.06.011.

Angouri, Jo \& Tseliga, Theodora (2010). 'You HAVE NO IDEA WHAT YOU ARE TALKING ABOUT!' From E-disagreement to E-impoliteness in two online fora. Journal of Politeness Research, 6, 57-82.

Aull, Bethany (2019). A study of phatic emoji use in WhatsApp communication. Internet Pragmatics, 2 (2), 206-232. doi: 10.1075/ip.00029.aul. 
Bardovi-Harlig, Kathleen, Sabrina Mossman \& Heidi E. Vellenga (2015). The effect of instruction on pragmatic routines in academic discussion. Language Teaching Research, 19 (3), 325-331. doi: $10.1177 / 1362168814541739$.

Barhoumi, Chokri (2015). The effectiveness of WhatsApp mobile learning activities guided by activity theory on students' knowledge management. Contemporary Educational Technology, 6 (3), $221-238$.

Baron, Naomi S. (2008). Always on: Language in an online and mobile world. New York: Oxford University Press.

Bernal, María (2007). Categorización sociopragmática de la cortesía y de la descortesía: Un estudio de la conversación coloquial española. Estocolmo: Stockholm University.

Bou-Franch, Patricia, Nuria Lorenzo-Dus \& Pilar Garcés-Conejos Blitvich (2012). Social Interaction in Youtube text-based polylogues: A study of coherence. Journal of Computer-Mediated Communication, 17 (4), 501-521.

Bouhnik, Dan \& Deshen, Mor (2014). WhatsApp goes to school: Mobile instant messaging between teachers and students. Journal of Information Technology Education: Research, 13, 217-231. doi: $10.28945 / 2051$.

Bourlai, Elli \& Susan C. Herring (2014). Multimodal communication on Tumblr: 'I have so many feels!' Proceedings of the 2014 ACM Conference on Web Science. Bloomington, Indiana, 171-175. doi: 10.1145/2615569.2615697.

Bravo, Diana (2008). Situación de habla, recursos comunicativos y factores lingüísticos en la interpretación de objetivos de cortesía. Cortesía y conversación: de lo escrito a lo oral. Valencia: Universitat de València, 12-24.

Brown, Penelope \& Stephen C. Levinson (1987). Politeness: Some universals in language usage. Cambridge: Cambridge University Press.

Calero Vaquera, María Luisa (2014). El discurso del WhatsApp: entre el Messenger y el SMS. Oralia, 17, 85-114.

Church, Karen \& Rodrigo De Oliveira (2013). What's up with Whatsapp?: Comparing mobile instant messaging behaviors with traditional SMS. Proceedings of the 15th international conference on human-computer interaction with mobile devices and services, 352-361.

Crystal, David (2006). Language and the Internet. Cambridge: Cambridge University Press.

Culpeper, Jonathan (1996). Towards an anatomy of impoliteness. Journal of Pragmatics, 25 (3), $349-367$.

Dresner, Eli \& Susan C. Herring (2010). Functions of the nonverbal in CMC: Emoticons and illocutionary force. Communication Theory, 20 (3), 249-268. doi: 10.1111/j.1468-2885.2010.01362.x.

Dresner, Eli \& Susan C. Herring (2013). Emoticons and illocutionary force. In Riesenfeld, D. \& G. Scarafil (eds.) Perspectives on theory of controversies and the ethics of communication. Dordrecht: Springer, $81-90$.

Dynel, Marta (2015). The landscape of impoliteness research. Journal of Politeness Research, 11 (2), 329-340. doi: 10.1515/pr-2015-0013.

Edstrom, Anne (2004). Expressions of disagreement by Venezuelans in conversation: Reconsidering the influence of culture. Journal of Pragmatics, 36 (8), 1499-1518. doi: 10.1016/j.pragma.2004.02.002.

Ersöz, Selva (2019). Understanding Whatsapp parent groups' dynamics: Group communication and information sharing. Manas Sosyal Araştırmalar Dergisi, 8 (1), 1167-1183.

Fernández-Amaya, Lucía (2019). Managing conflict originated by feminism: A case study from WhatsApp interaction among Spanish family members. Journal of Language Aggression and Conflict. http://doi.org/10.1075/jlac.00032.fer 
Fernández-Amaya, Lucía, Hernández-López, María de la O \& Pilar Garcés-Conejos Blitvich (2014). Spanish travellers' expectations of service encounters in domestic and international settings. Tourism, Culture and Communication, 14 (2), 117-134.

Flores-Salgado, Elizabeth \& Teresa A. Castineira-Benitez (2018). The use of politeness in WhatsApp discourse and move 'requests'. Journal of Pragmatics, 133, 79—92.

Fundación Telefónica. 2018. "Informe de la sociedad digital en España." https://www.fundaciontelefonica.com/ arte_cultura/sociedad-de-la-informacion/sdie-2018/.

Ganasegeran, Kurubaran, Pukunan Renganathan, Abdul Rashid \& Sami A.R. Al-Dubai (2017). The $\mathrm{m}$-Health revolution: Exploring perceived benefits of WhatsApp use in clinical practice. International Journal of Medical Informatics, 97, 145-151. doi: 10.1016/j.jimedinf.2016.10.013.

Garcés-Conejos Blitvich, Pilar (2010). A genre approach to the study of im-politeness. International Review of Pragmatics, 2, 46-94.

García-Gómez, Antonio (2018). Managing conflict on WhatsApp: A contrastive study of British and Spanish family disputes. Journal of Language Aggression and Conflict, 6 (2), 318-340. doi: 10.1075/jlac.00015.gar.

Georgakopoulou, Alexandra (2001). Arguing about the future: on indirect disagreements in conversation. Journal of Pragmatics, 33, 1881-1900.

Goodwin, Marjorie Harness (1983). Aggravated correction and disagreement in children's conversations. Journal of Pragmatics, 7 (6), 657-677. doi: 10.1016/0378 2166(83)90089-9.

Graham, Sage (2007). Disagreeing to agree: Conflict, (im)politeness and identity in a computer-mediated community. Journal of Pragmatics, 39, 742-759. doi: 10.1016/j.pragma.2006.11.017.

Gray, Peter H. (2001). A problem-solving perspective on knowledge management practices. Decision Support Systems, 31 (1), 87-102. doi:10.1016/S0167-9236(00)00121-4.

Hay, Jennifer (2000). Functions of humor in the conversations of men and women. Journal of Pragmatics, 32 (6), 709-742.

Hernández Flores, Nieves (2003). Cortesía y contextos socioculturales en la conversación de familiares y amigos. Actas del primer coloquio del programa EDICE 'La perspectiva no etnocentrista de la cortesía: identidad sociocultural de las comunidades hispanohablantes'. Estocolmo: Programa EDICE, Universidad de Estocolmo, 121-127.

Hernández-López, María de la O (2016). Disagreement and degrees of assertiveness in service encounters: Purchase vs problem-solving interactions. International Journal of Society, Culture \& Language, 4 (2), 87-104.

Hernández-López, María de la O \& Lucía Fernández-Amaya (2019). What makes (im)politeness for travellers? Spanish tourists' perceptions at national and international hotels. Journal of Politeness Research, 15 (2), 195-222. doi: 10.1515/pr-2016-0060.

Herring, Susan C. (2015). New frontiers in interactive multimodal communication. In Georgopoulou, A. \& T. Spilloti (eds.) The Routledge handbook of language and digital communication. London: Routledge, 398-402.

Jewitt, Carey (2013). Multimodal methods for researching digital technologies. In Price, S., C. Jewitt $\&$ B. Brown (eds.) The SAGE handbook of digital technology research. London: SAGE Publications, $250-265$.

Johnston, Maximiliam, Dominic King, Sonal Arora, Nebil Behar, Thanos Athanasiou, Nick Sevdalis \& Ara Darzi (2015). Smartphones let surgeons know Whatsapp: An analysis of communication in emergency surgical teams. The American Journal of Surgery, 209 (1), 45-51. doi: 10.1016/j.amjsurg.2014.08.030.

Jones, Rodney H. \& Hafner Christoph, A. (2012). Understanding digital literacies: A practical introduction. London: Routledge. 
Kakavá, Christina (1993). Negotiation of disagreement by Greeks in conversations and classroom discourse (Unpublished doctoral dissertation). Georgetown University, USA.

Kakavá, Christina (2002). Opposition in modern Greek discourse: Cultural and contextual constraints. Journal of Pragmatics, 34 (10), 1537-1568. doi: 10.1016/S0378-2166(02)00075-9.

Kamel Boulos, Maged, Dean Giustini \& Steve Wheeler (2016). Instagram and WhatsApp in health and healthcare: An overview. Future Internet 8 (3), 37. doi: 10.3390/fi8030037.

Kreutel, Karen (2007). "I'm Not Agree with You.” ESL Learners' Expressions of Disagreement. TESL-EJ, 11 (3), 1-20.

Langlotz, Andreas \& Miriam A. Locher (2012). Ways of communicating emotional stance in online disagreements. Journal of Pragmatics, 44, 1591-1606.

Locher, Miriam A. (2004). Power and politeness in action: Disagreement in oral communication. Mouton de Gruyter, Berlin and New York.

Maíz Arévalo, Carmen (2018). Emotional self-presentation on Whatsapp: Analysis of the profile status. Russian Journal of Linguistics, 22 (1), 144 —160. doi: 10.22363/2312-9182-2018-22-1-144-160.

Malamed, Lewis H. (2010). How to disagree agreeably. In Martínez-Flor, A. \& E. Usó-Juan (eds.) Speech act performance: Theoretical, empirical and methodological issues. Amsterdam/Philadelphia: John Benjamins Publishing Company, 199-216. doi: 10.1075/11lt.26.12mal.

Masoumeh, Mehregan, Abbass Eslamirasekh, Dabaghi Azizollah \& Jafari Seresht Davood (2013). Disagreement expressions in the discourse of young Persian speakers. Procedia Social and Behavioral Sciences, 70, 598-604.

Netz, Hadar (2014). Disagreement patterns in gifted classes. Journal of Pragmatics, 61, 142-160. doi: 10.1016/j.pragma.2013.09.007.

O'Hara, Kenton, Michael Massimi, Richard Harper, Simon Rubens \& Jessica Morris (2014). Everyday dwelling with WhatsApp. Proceedings of the 17th ACM conference on computer supported cooperative work and social computing, 1131-1143.

Pérez-Sabater, Carmen (2012). The linguistics of social networking: A study of writing conventions on Facebook. Linguistik Online, 56 (6), 81—93. doi: 10.13092/lo.56.257.

Pérez-Sabater, Carmen (2015). Discovering language variation in Whatsapp text interactions. Onomázein: Revista Semestral de Lingüistica, Filología y Traducción, 31 (1), 113-126. doi: 10.7764/onomazein.31.8.

Petitjean, Cécile \& Etienne Morel (2017). 'Hahaha': Laughter as a resource to manage WhatsApp conversations. Journal of Pragmatics, 110, 1-19. doi: 10.1016/j.pragma.2017.01.001.

Pomerantz, Anita (1984). Agreeing and disagreeing with assessments: Some features of preferred/ dispreferred turn shaped. Cambridge: Cambridge University Press.

Rees-Miller, Janie (2000). Power, severity, and context in disagreement. Journal of Pragmatics, 32 (8), 1087-1111. doi: 10.1016/S0378 2166(99)00088-0.

Rubio-Romero, Juana \& Marta Perlado de Espinosa (2015). El fenómeno WhatsApp en el contexto de la comunicación personal: una aproximación a través de los jóvenes universitarios. Revista ICONO14. Revista científica de Comunicación y Tecnologías emergentes, 13 (2), 73-94. doi: 10.7195/ri14.v13i2.818.

Sacks, Harvey (1987). On the preference for agreement and contiguity in sequence in conversation. Talk and Social Organization, 54, 54-69.

Sampietro, Agnese (2016a). Emoticonos y multimodalidad. El uso del pulgar hacia arriba en WhatsApp. Aposta. Revista de Ciencias Sociales, 69, 271-295.

Sampietro, Agnese (2016b). Exploring the punctuating effect of emoji in Spanish Whatsapp chats. Lenguas Modernas, 47, 91-113. 
Sánchez-Moya, Alfonso \& Olga Cruz-Moya (2015a). Whatsapp, textese, and moral panics: Discourse features and habits across two generations. Procedia-Social and Behavioral Sciences, 173, 300306. doi: 10.1016/j.sbspro.2015.02.069.

Sánchez-Moya, Alfonso \& Olga Cruz-Moya (2015b). 'Hey there! I am using Whatsapp': A preliminary study of recurrent discursive realisations in a corpus of Whatsapp statuses. Procedia-Social and Behavioral Sciences, 212, 52-60. doi: 10.1016/j.sbspro.2015.11.298.

Schiffrin, Deborah (1984). Jewish argument as sociability. Language in Society, 13, 311-335.

Schnurr, Stephanie (2010). Humour. In Locher, M. A. \& S.L. Graham (eds.) Interpersonal pragmatics. Berlin: Mouton de Gruyter, 307-326.

Shum, Winnie \& Cynthia Lee (2013). (Im)politeness and disagreement in two Hong Kong Internet discussion forums. Journal of Pragmatics, 50, 52-83.

Sifianou, Maria (2012). Disagreements, face and politeness. Journal of Pragmatics, 44, 1554-1564.

Sornig, Karl (1977). Disagreement and contradiction as communicative acts. Journal of Pragmatics, 1 (4), 347 374. doi: 10.1016/0378 2166(77)90028-5.

Swales, John (1990). Genre analysis. English in academic and research settings. Cambridge: Cambridge University Press.

Tannen, Deborah (1981). New York Jewish conversational style. International Journal of the Sociology of Language, 30, 133-149. doi: 10.1515/ijsl.1981.30.133.

Tannen, Deborah (1984). Conversational style: Analyzing talk among friends. Oxford / New York: Oxford University Press.

Tannen, Deborah (1990). You just don't understand: Women and men in conversation. New York: Ballantine.

Tannen, Deborah (1998). The argument culture. New York: Random House.

Tjosvold, Dean (2008). The conflict-positive organization: It depends upon us. Journal of Organizational Behavior, 29 (1), 19-28. doi: 10.1002/job.473.

$\mathrm{Xu}$, Lingling (2017). Disagreement studies reviewed and my coy disagreements. Studies in English Language Teaching, 5 (4), 679—694. doi: 10.22158/selt.v5n4p679.

Yus, Francisco (2011). Cyberpragmatics. Internet-mediated communication in context. Amsterdam/ Philadelphia: John Benjamins Publishing Company. doi: 10.1075/pbns.213.

Yus, Francisco (2014). Not all emoticons are created equal. Linguagem em (Dis)curso, 14 (3), 511 529. doi: 10.1590/1982-4017-140304-0414.

Yus, Francisco (2017). Contextual constraints and non-propositional effects in Whatsapp communication. Journal of Pragmatics, 114, 66-86. doi:10.1016/j.pragma.2017.04.003.

Zhu, Weihua (2014). Managing relationships in everyday practice: The case of strong disagreement in mandarin. Journal of Pragmatics, 64, 85-87. doi:10.1016/j.pragma.2014.01.010.

\section{Article history:}

Received: 27 September 2019

Revised: 14 October 2019

Accepted: 16 November 2019

\section{История статьи:}

Дата поступления в редакцию: 14 сентября 2019

Дата принятия к печати: 16 октября 2019 


\section{Bionote:}

LUCÍA FERNÁNDEZ-AMAYA is Lecturer in English at the Department of Philology and Translation, Pablo de Olavide University, Seville. She holds a Ph.D. in English Linguistics from the University of Seville. She teaches English as a foreign language (Translation and Interpretation Bachelor's Degree) and "Intercultural Competence" (Master's Degree in International Communication, Translation and Interpretation). Her research interests and publications focus on pragmatics and translation, cross-cultural pragmatics, (im)politeness, the language of service encounters and digital discourse. Her most recent publications include articles published in the Journal of Language Aggression and Conflict (2019) and the Journal of Politeness Research (2019).

Contact information:1ferama@upo.es

\section{Сведения об авторе:}

ЛЮСИЯ ФЕРНАНДЕС-АМАЯ - доктор лингвистики, преподает английский язык межкультурную коммуникацию на факультете филологии и перевода Университета им. Пабло де Олавиде в Севилье. Ее исследовательские интересы сосредоточены на прагматике и переводе, кросс-культурной прагматике, (не)вежливости и цифровом дискурсе. Среди ее последних публикаций - статьи в журналах Journal of Language Aggression and Conflict (2019) и Journal of Politeness Research (2019).

Контактная информация: 1ferama@upo.es 